American Journal of Environmental Sciences 7 (4): 377-382, 2011

ISSN 1553-345X

(C) 2011 Science Publications

\title{
The Effect of Bio-Fuel Blends and Fuel Injection Pressure on Diesel Engine Emission for Sustainable Environment
}

\author{
Kandasamy Muralidharan and Palanisamy Govindarajan \\ Sona College of Technology, Tamilnadu, India
}

\begin{abstract}
Problem statement: Diesel engine emits more pollutants to atmosphere causing air pollution. This necessitates the search of a renewable alternate fuel which is environment friendly. The objective of this research was to investigate the environmental aspects of pongamia bio-fuel in a single cylinder diesel engine with the influence of fuel injection pressure. Approach: Bio-fuel was prepared from non-edible Pongamia pinnata oil by transesterification and used as a fuel in C.I engine. The effect of fuel injection pressure on the engine emission characteristics of a single cylinder direct injection diesel engine has been experimentally investigated using pongamia pinnata methyl ester and its blends with diesel fuel from 0-30\% with an increment of 5\% at full load. The tests were conducted at five different injection pressures $\left(190,200,210,220\right.$ and $230 \mathrm{KN} \mathrm{m}^{-2}$ ) by means of adjusting injector spring tension. Results: Compared to diesel, blend B5 exhibits lower engine emissions of unburnt hydrocarbon, carbon monoxide, oxides of nitrogen and carbon di oxide at full load. The High injection pressure of $220 \mathrm{KN} \mathrm{m}^{-2}$ shows lesser emissions of unburnt hydrocarbon and carbon monoxide while oxides of nitrogen and carbon dioxide are found to be slightly higher than diesel and blends at full load. Conclusion: From the test results, it was found that a high injection pressure of $220 \mathrm{KN} \mathrm{m}^{-2}$ causes better atomization with improved engine emission characteristics for diesel and blends at full load. Moreover blend B5 showed best results at $220 \mathrm{KN} \mathrm{m}^{-2}$ injection pressure.
\end{abstract}

Key words: Pongamia pinnata methyl ester, diesel, injection pressure, emissions

\section{INTRODUCTION}

Fuels are inevitable for industrial development and growth of any country. The life span of fossil fuel resources has been terrifying. Biodiesel, a renewable source of energy seems to be an ideal solution for global energy demands including India as well (Sharma and Singh, 2009). In recent years, Biodiesel has become more attractive as an alternative fuel for diesel engines because of its environmental benefits and the fact that it is made from renewable resources (Singh and Singh, 2010).

A number of studies have shown that triglycerides produced from vegetable oil hold promise as alternative fuels for diesel engines. However, the high viscosity, low volatility and poor cold flow properties of triglycerides, which result in severe engine deposits, injector choking and piston ring sticking have prevented triglycerides from being used directly in diesel engine. Various blends of pongamia biodiesel with diesel have been tried, but B-20 has been found to be the most appropriate blend (Murugesan et al., 2009). A suitable way to improve the fuel properties of triglycerides is the catalytic transesterification of triglycerides with alcohols to form mono-alkyl esters of long chain fatty acids named as biodiesel which is similar to diesel fuel. The performance parameters are found to be similar to diesel with a significant reduction in emission levels are observed at all loading conditions (Demirbas, 2008; Srivastava and Prasad, 2000). The fatty acid methyl ester content was determined by a standard titrimetry method (Meher et al., 2006).

Bio diesel prepared from vegetable oil after transesterification reaction shows a similar performance to diesel at all loading conditions and can be used as alternate fuel to diesel without any modifications in engine design (Bozbas, 2008) and the direct use of vegetable oils for both direct and indirect injection type diesel engines is unsatisfactory due to their high viscosities and low volatilities (Rakopoulos et al., 2006). Ethyl ester produced from waste vegetable oil by transesterification process with ethanol can be used as a substitute fuel for diesel engine. Engine performance and exhaust emission for $100 \%$ ester showed better performance to diesel. Since vegetable oils have cetane numbers close to those of diesel fuel, they can be used in existing compression ignition engines with little or no modifications (Al-Widyan et al., 2002). 
In the performance and emission test carried out in a naturally aspirated single cylinder diesel engine fuelled with waste vegetable cooking oil it has been found that maximum power and torque was obtained for blend $\mathrm{B} 20$ with lower concentration of $\mathrm{HC}$ and $\mathrm{CO}$ than diesel. Oxygen content in the fuel is main reason for better combustion and HC emissions (Najafi et al., 2007). The behavior of soybean oil in diesel engine was evaluated using performance and emission tests carried out in single cylinder diesel engine and it was observed that soybean methyl ester and its blends shows significant reduction of carbon monoxide and smoke emissions than diesel while the performance parameters analyzed are not satisfactory. So the usage of soybean methyl ester was suitable for partial substitution with diesel at all loads without any engine modification (Qi et al., 2010). The behavior of karanja methyl ester (Pongamia pinnata methyl ester) in a single cylinder diesel engine at an Injection Pressure of $200 \mathrm{KN} \mathrm{m}^{-2}$ was analyzed using the performance and emission parameters. Lower emissions are obtained for blend B20 with improved performance than diesel. It was found that biodiesel can be used as an alternative to diesel in a C.I. engine without any engine modifications (Nagarhalli et al., 2010).

Experiments have been conducted on a 4 cylinder, 2 stroke direct injection diesel engine to analyze the effect of fuel injection pressure over the Performance evaluation of diesel. Performance parameters are evaluated for different injection pressures from 180-220 $\mathrm{KN} \mathrm{m}^{-2}$. According to the results, the best performance of the pressure injection has been obtained at $220 \mathrm{KN}$ $\mathrm{m}^{-2}$, specific fuel consumption has been obtained at 180 $\mathrm{KN} \mathrm{m}{ }^{-2}$ for variation loads-fixed speed (Bakar et al., 2008). Experiments have been conducted to study the effect of injection pressure on the combustion process and exhaust emissions of a direct injection diesel engine fuelled with Orange Skin Powder Diesel Solution (OSPDS). The different injection pressures studied were 215, 235 and $255 \mathrm{KN} \mathrm{m}^{-2}$. Test Results have shown that the combustion, performance and emission characteristics of the engine operating on the test fuels at $235 \mathrm{KN} \mathrm{m}^{-2}$ injection pressure were better than other injection pressures due to good atomization and improved combustion (Purushothaman and Nagarajan, 2009).

\section{MATERIALS AND METHODS}

The experiments were carried out on a four-stroke, naturally aspirated, single cylinder direct injection C.I. engine. Details of the engine specifications are shown in Table 1. The engine was coupled to an eddy current dynamometer to control engine speed and load. The output shaft of eddy current dynamometer is fixed to a strain gauge type load cell for measuring applied load to the engine. Engine cooling water inlet temperature, cooling water outlet temperature and Engine exhaust temperature were measured using $\mathrm{K}$ type thermocouples. The air flow rate to the engine is measured by using the mass air flow sensor and the fuel consumption was measured by using two optical slot sensors placed at either levels of burette. A piezo electric pressure transducer is mounted on engine head to measure combustion pressure. Engine crank angle was measured by using crank angle encoder mounted on the camshaft. Engine speed is measured using RPM sensor. The schematic diagram of experimental setup is shown in Fig. 1. The exhaust emissions (CO, unburned $\mathrm{HC}, \mathrm{NO}_{\mathrm{x}}$ and $\mathrm{CO}_{2}$ ) were measured using Multi gas analyzer (NETEL). The analyzer specifications are detailed in Table 2.

Table 1: Technical specifications of the test engine

\begin{tabular}{ll}
\hline Engine make & Kirlosker \\
\hline Cylinder number & 1 \\
Cylinder bore & $80 \mathrm{~mm}$ \\
Stroke & $110 \mathrm{~mm}$ \\
Rated power & $5 \mathrm{BHP}$ \\
Compression ratio & $17: 1$ \\
Engine Operating Speed & $1500 \mathrm{Rpm}^{-2}$ \\
Fuel Injection Pressure & $210 \mathrm{KN} \mathrm{m}^{-2}$ \\
Original injection timing & $23^{\circ} \mathrm{CA} \mathrm{BTDC}$ \\
Type of Loading & Eddy Current Dynamometer \\
Type of Cooling & Water \\
\hline
\end{tabular}

Table 2: Analyzer specifications

\begin{tabular}{lll}
\hline Parameter & Range & Resolution \\
\hline $\mathrm{CO}$ & $0-9.99 \%$ vol. & $0.01 \%$ \\
$\mathrm{HC}$ & $0-15000 \mathrm{ppm}$ & $1 \mathrm{ppm}$ \\
$\mathrm{CO}_{2}$ & $0-20 \% \mathrm{vol}$. & $0.10 \%$ \\
$\mathrm{O}_{2}$ & $0-25 \%$ & $0.01 \%$ \\
$\mathrm{NO}_{x}$ & $0-5000 \mathrm{ppm}$ & $1 \mathrm{ppm}$ \\
\hline
\end{tabular}

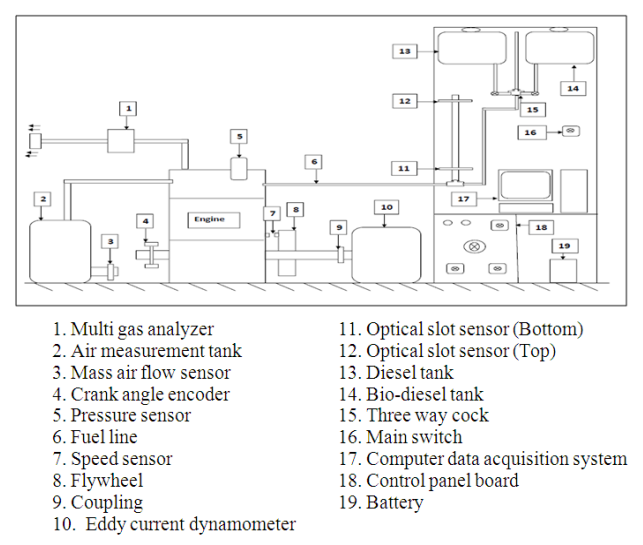

Fig. 1: Schematic diagram of experimental set up for engine test rig 
Am. J. Environ. Sci., 7 (4): 377-382, 2011

Table 3: Properties of tested fuels

\begin{tabular}{llllllll}
\hline Fuel blend & $\begin{array}{l}\text { Density } \\
\left(\mathrm{Kg} \mathrm{m}^{-3}\right)\end{array}$ & $\begin{array}{l}\text { Calorific } \\
\text { value }(\mathrm{KJ} / \mathrm{Kg})\end{array}$ & $\begin{array}{l}\text { Viscosity } \\
\mathrm{cSt} \text { at } 30^{\circ} \mathrm{C}\end{array}$ & $\begin{array}{l}\text { Flash } \\
\text { point }{ }^{\circ} \mathrm{C}\end{array}$ & $\begin{array}{l}\text { Fire } \\
\text { point }{ }^{\circ} \mathrm{C}\end{array}$ & $\begin{array}{l}\text { Cloud } \\
\text { point }{ }^{\circ} \mathrm{C}\end{array}$ & $\begin{array}{l}\text { Pour } \\
\text { point }{ }^{\circ} \mathrm{C}\end{array}$ \\
\hline Diesel & 836 & 43,415 & 2.87 & 46 & 52 & 4.0 & 2.0 \\
B5 & 839 & 43,192 & 4.12 & 55 & 61 & 4.6 & 2.3 \\
B10 & 842 & 42,969 & 5.34 & 62 & 73 & 4.8 & 2.5 \\
B15 & 845 & 42,740 & 6.56 & 70 & 85 & 5.0 & 2.8 \\
B20 & 848 & 42,511 & 7.78 & 78 & 98 & 5.3 & 3.1 \\
B25 & 851 & 42,300 & 8.96 & 87 & 110 & 5.6 & 3.5 \\
B30 & 854 & 42,077 & 9.80 & 98 & 124 & 5.8 & 3.8 \\
\hline
\end{tabular}

Viscosity is the major problem for the bio-diesel which imposes lot of problems for engine. In comparison to diesel $(2.87 \mathrm{cSt})$ the viscosity of biodiesel $(38 \mathrm{cSt})$ is much higher, in raw oil it is found to be $58.54 \mathrm{cSt}$ which is reduced to the $38 \mathrm{cSt}$ by transesterification process by virtue of removal of fats in the form of glycerol, viscosity of the esters up to $40 \%$ blends can be used in unmodified engine.

The methyl ester was blended with diesel in various proportions from $0-30 \%$ by volume (B5, B10, $\mathrm{B} 15, \mathrm{~B} 20, \mathrm{~B} 25$ and B30) with the help of a magnetic stirrer. The blends were stirred continuously to achieve stable property values. The properties of various fuels tested are analyzed in Table 3. The relative density of bio-diesel-diesel blends was measured by means of hydrometer. A redwood viscometer with measuring cup and a thermometer was used to measure the viscosity of all samples. The dynamic viscosity measurements were carried out as $\mathrm{cSt}$ at $30^{\circ} \mathrm{C}$ temperature. Flash Point open cup apparatus was used to measure the flash points of the bio-diesel-diesel blends. The heating values of the bio-diesel-diesel were measured in bomb calorimeter according to ASTM D2015 standard method. The cloud and pour point of fuel samples are measured in a Pour and Cloud point apparatus where the test samples are placed in a controlled environment to below $30^{\circ} \mathrm{C}$.

Diesel and blends were tested at full load condition at the rated speed. During each trial, the engine was started and after it attains stable condition, important parameters related to thermal performance of the engine such as the time taken for $20 \mathrm{~cm}^{3}$ of fuel consumption, applied load, the ammeter and voltmeter readings were measured and recorded. Also, the engine emission parameters like $\mathrm{CO}, \mathrm{CO}_{2}, \mathrm{HC}, \mathrm{NO}_{\mathrm{x}}$ and the exhaust gas temperature from the online exhaust gas analyzer were noted and recorded. The original injection timing of the engine is $23^{\circ} \mathrm{CA}$ BTDC and by varying the fuel injector spring tension; measurements are taken for five different injection pressures $(190,200,210,220,230$ $\mathrm{KN} \mathrm{m}^{-2}$ ) at full load condition. All test runs were conducted on the test-bench. In each run, engine speed and load were recorded. For each injection pressure, the combination of all tests included engine setting at full load in rated speed. Each test was repeated three times.
The values given in this study are the average of these three results.

\section{RESULTS AND DISCUSSION}

Tests were carried out at five different injection pressures (190, 200, 210, 220 and $230 \mathrm{KN} \mathrm{m}^{-2}$ ) at constant speed of $1500 \mathrm{rpm}$ in standard injection timing of $23^{\circ}$ CA BTDC for diesel and blends B5, B10, B15, B20, B25 and B30 at full load condition. Engine emission characteristics of all the fuels tested are evaluated and presented at full load condition.

\section{Emission analysis:}

Oxides of nitrogen $\left(\mathbf{N O}_{\mathbf{x}}\right)$ : The formation of $\mathrm{NO}_{\mathrm{x}}$ is strongly dependent upon in-cylinder gas temperature and the availability of oxygen during combustion reaction. It is clear from Fig. 2 that by increasing the injection pressure $\mathrm{NO}_{\mathrm{x}}$ emission shows an increasing trend up to $220 \mathrm{KN} \mathrm{m}^{-2}$. Increase of injection pressure tends to increase of $\mathrm{NO}_{\mathrm{x}}$ emission due to the higher heat release rate in the premixed combustion phase with diesel. At very high injection pressure of $230 \mathrm{KN} \mathrm{m}^{-2}$, $\mathrm{NO}_{\mathrm{x}}$ emission decreases slightly for diesel and blends which is because of lower peak cylinder pressure arises due to lesser heat release rate during combustion leads to lesser spray penetration inside the combustion chamber.

The increase of blend concentration in diesel tends to increase the $\mathrm{NO}_{\mathrm{x}}$ levels during combustion due to the presence of oxygen content in biodiesel which enhances combustion process. The minimum value of $\mathrm{NO}_{\mathrm{x}}$ was observed for diesel and blends B5, B10 at full load in lower injection pressure of $190 \mathrm{KN} \mathrm{m}^{-2}$ as shown in the Fig. 5. Compared to standard injection pressure, $\mathrm{NO}_{\mathrm{x}}$ emission rate at $220 \mathrm{KN} \mathrm{m}^{-2}$ was increased about an average percentage of $2.82 \%$ for the fuels tested. At very high injection pressure of $230 \mathrm{KN} \mathrm{m}{ }^{-2}, \mathrm{NO}_{\mathrm{x}}$ emission for diesel and blends B5, B10, B15, B20, B25, B30 showed a significant reduction of $6.52,1.176,7.04$, $3.46,2.88,3.33$ and $1.45 \%$ respectively on comparing to standard injection pressure. B5 exhibits lower $\mathrm{NO}_{\mathrm{x}}$ emission than diesel at higher injection pressures compared to all fuels tested at full load. 


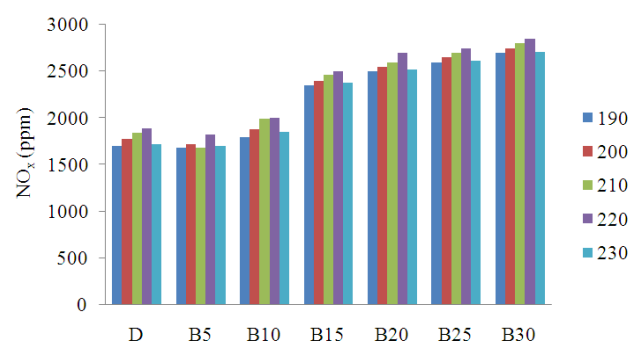

Fig. 2: Effect of $\mathrm{NO}_{\mathrm{x}}$ at various injection pressures at full load

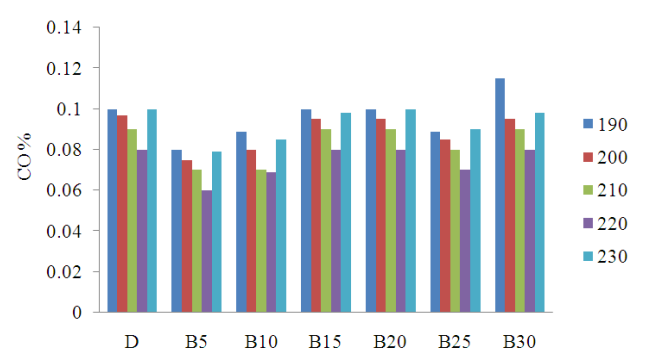

Fig. 3: Variation of $\mathrm{CO}$ emission at different injection pressure at full load

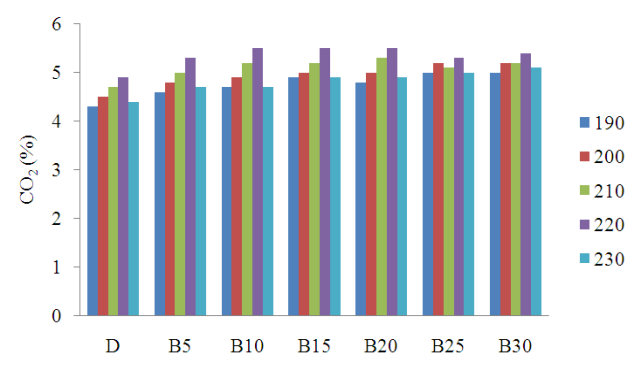

Fig. 4:Influence of injection pressure on $\mathrm{CO}_{2}$ emission for different blends at full load

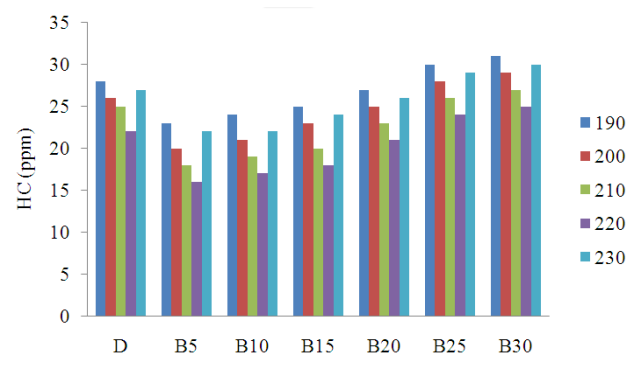

Fig. 5: Effect of injection pressure on $\mathrm{HC}$ emission for different blends at full load

Carbon monoxide (CO): The effect of injection pressure variation over $\mathrm{CO}$ emission for diesel and blends at full load is shown in Fig. 3. Test results show that $\mathrm{CO}$ emission decreases with the increase of injection pressure for all fuels up to $220 \mathrm{KN} \mathrm{m}^{-2}$ while $\mathrm{CO}$ emission increases at high injection pressure of 230 $\mathrm{KN} \mathrm{m}^{-2}$ due to poor atomization resulting in incomplete combustion. Increase of injection pressure ensures better mixing of fuel with air improves combustion process reducing $\mathrm{CO}$ emission. The emission rate is found to be higher in low injection pressure of $190 \mathrm{KN}$ $\mathrm{m}^{-2}$ due to incomplete combustion and lower emission values are obtained for an injection pressure of $220 \mathrm{KN}$ $\mathrm{m}^{-2}$ for all fuels. Compared to standard injection pressure, significant reduction of $\mathrm{CO}$ emission was observed in percentage of 11.11, 14.29, 1.43, 11.11, $11.11,12.5$ and $11.11 \%$ for diesel and blends B5, B10, B15, B20, B25, B30 respectively at an injection of 220 $\mathrm{KN} \mathrm{m}^{-2}$. Lowest value of $\mathrm{CO}$ emission was obtained for blend $\mathrm{B} 5$ at $220 \mathrm{KN} \mathrm{m}^{-2}$ injection pressure than diesel at full load.

Carbon dioxide $\left(\mathrm{CO}_{2}\right)$ : For the various fuels tested, $\mathrm{CO}_{2}$ emission increases with the increase of injection pressure and increasing the concentration of methyl ester in diesel. This is because increase of injection pressure tends to finer fuel spray mixes fuel and air thoroughly makes the combustion process complete. The variation of $\mathrm{CO}_{2}$ emission for different injection pressure for diesel and blends at full load are represented in the Fig. 4. It was found that by increasing the injection pressure from $190-220 \mathrm{KN} \mathrm{m}^{-2}$ increases $\mathrm{CO}_{2}$ emission gradually for all the fuels tested while at $230 \mathrm{KN} \mathrm{m}^{-2}$ injection pressure, $\mathrm{CO}_{2}$ emission slightly decreases. This is because at very high injection pressure of $230 \mathrm{KN} \mathrm{m}^{-2}$, fuel droplets size are very fine they do not find air to form a homogeneous mixture leading to incomplete combustion. $\mathrm{CO}_{2}$ emission rate was found to be higher for diesel and blends at an injection pressure of $220 \mathrm{KN} \mathrm{m}^{-2}$ and lower values are obtained for the fuels at $190 \mathrm{KN} \mathrm{m}^{-2}$ pressure. At low injection pressure, fuel droplet diameter gets enlarged resulting in longer ignition delay leading to incomplete combustion. Compared to standard injection pressure of $210 \mathrm{KN} \mathrm{m}^{-2}$, a significant reduction in $\mathrm{CO}_{2}$ emission was observed at lowest injection pressure of $190 \mathrm{KN}$ $\mathrm{m}^{-2}$ in percentage of $8.51,8,9.62,5.77,9.43,1.96$ and $3.85 \%$ for diesel and blends B5, B10, B15, B20, B25, $\mathrm{B} 30$ respectively. Blend $\mathrm{B} 5$ exhibits slightly higher $\mathrm{CO}_{2}$ emission than other fuel tested at all injection pressures.

Hydrocarbon (HC): It was observed from Fig. 5 that the unburnt hydrocarbon emission tends to decrease with the increase of injection pressure and increases while increasing the concentration of methyl ester in diesel. This may be due to complete combustion since 
the usage of oxygenated methyl ester as fuel. HC emission was found to be higher for almost all the fuels tested except blends B5, B10 and B15. Increasing the blend concentration in diesel increases $\mathrm{HC}$ emission since the high viscosity of methyl ester may cause poor atomization resulting in incomplete combustion. A significant reduction in $\mathrm{HC}$ emission was obtained at high injection pressure of $220 \mathrm{KN} \mathrm{m}^{-2}$ for diesel and blends in percentage of $12,11.11,10.53,10,8.7,7.7$ and $7.41 \%$ respectively at full load. Compared to standard injection pressure, it was noticed that Blend B5 emits lower unburnt hydrocarbon than all the fuels at $220 \mathrm{KN} \mathrm{m}^{-2}$ injection pressure.

\section{CONCLUSION}

In this study, the effect of fuel injection pressure on the engine emission of a direct injection diesel engine has been experimentally investigated using pongamia methyl ester blends with diesel fuel. Injection pressure was varied from $190-230 \mathrm{KN} \mathrm{m}^{-2}$ in steps of $10 \mathrm{KN} \mathrm{m}^{-2}$ at standard injection timing of $23^{\circ} \mathrm{CA}$ BTDC and the following observations were made:

- High fuel injection pressure of $220 \mathrm{KN} \mathrm{m}^{-2}$ showed improved emission characteristics of pongamia methyl ester with diesel at full load

- Blend B5 at $220 \mathrm{KN} \mathrm{m}^{-2}$ injection pressure shows lower emissions than diesel and blends at full load.

- B5 exhibits slightly lower $\mathrm{NO}_{\mathrm{x}}$ emission than diesel at higher injection pressures compared to all fuels tested at full load

- Lowest value of CO emission of $0.06 \%$ was obtained for blend $\mathrm{B} 5$ at high injection pressure of $220 \mathrm{KN} \mathrm{m}^{-2}$ and Increase of $\mathrm{CO}_{2}$ emission was observed for diesel and blends at this pressure

- Unburnt Hydrocarbon emission was found to be higher for almost all the fuels tested except B5 and B10 at all injection pressures

\section{ACKNOWLEDGMENT}

The researchers acknowledge the support given by the management of the institution (Sona College of Technology) and providing opportunity for doing research in the Internal Combustion Engine laboratory.

\section{REFERENCES}

Al-Widyan, M.I., G. Tashtoush and M. Abu-Qudais, 2002. Utilization of ethyl ester of waste vegetable oils as fuel in diesel engines. Fuel Process.
Technol., 76: 91-103. DOI: 10.1016/S03783820(02)00009-7

Bakar, R.A., Semin and A.R. Ismail, 2008. Fuel injection pressure effect on performance of direct injection diesel engines based on experiment. Am. J. Applied Sci., 5: 197-202. DOI: 10.3844/ajassp.2008.197.202

Bozbas, K., 2008. Biodiesel as an alternative motor fuel: Production and policies in the European Union. Renew. Sustain. Energy Rev., 12: 542-552. DOI: 10.1016/J.RSER.2005.06.001

Demirbas, A., 2008. Biodiesel: A Realistic Fuel Alternative for Diesel Engines. 1st Edn., SpringerVerlag, London, ISBN: 9781846289941, pp: 208.

Meher, L.C., D.V. Sagar and S.N. Naik, 2006. Technical aspects of biodiesel production by transesterification-a review. Renew. Sustain. Energy Rev., 10: 248-268. DOI: 10.1016/J.RSER.2004.09.002

Murugesan, A., C. Umarani, T.R. Chinnusamy, M. Krishnan and R. Subramanian et al., 2009. Production and analysis of bio-diesel from nonedible oils-A review. Renew. Sustain. Energy Rev., 13: 825-834. DOI: 10.1016/j.rser.2008.02.003

Nagarhalli, M.V., V.M. Nandedkar and K.C. Mohite, 2010. Emission and performance characteristics of karanja biodiesel and its blends in a C.I. engine and its economics. ARPN J. Eng. Applied Sci., 5: 5256.

Najafi, G., B. Ghobadian, T.F. Yusaf and H. Rahimi, 2007. Combustion analysis of a CI engine performance using waste cooking Biodiesel fuel with an artificial neural network aid. Am. J. Applied Sci., 4: 759-767. DOI: 10.3844/ajassp.2007.759.767

Purushothaman, K. and G. Nagarajan, 2009. Effect of injection pressure on heat release rate and emissions in $\mathrm{CI}$ engine using orange skin powder diesel solution. Energy Conver. Manage., 50: 962969. DOI: 10.1016/j.enconman.2008.12.030

Qi, D.H., H. Chen, L.M. Geng and Y.Z.H. Bian, 2010. Experimental studies on the combustion characteristics and performance of a direct injection engine fueled with biodiesel/diesel blends. Energy Conver. Manage., 51: 2985-2992. DOI: 10.1016/j.enconman.2010.06.042

Rakopoulos, C.D., K.A. Antonopoulo, D.C. Rakopoulos, D.T. Hountalas and E.G. Giakoumis, 2006. Comparative performance and emissions study of a direct injection Diesel engine using blends of Diesel fuel with vegetable oils or biodiesels of various origins. Energy Conver. Manage., $\quad 47$ : 3272-3287. DOI: 10.1016/j.enconman.2006.01.006 
Singh, S.P. and D. Singh, 2010. Biodiesel production through the use of different sources and characterization of oils and their esters as the substitute of diesel: A review. Renew. Sustain. Energy Rev., 14: 200-216. DOI: 10.1016/j.rser.2009.07.017
Sharma, Y.C. and B. Singh, 2009. Development of Biodiesel: Current scenario. Renew. Sustain. Energy Rev., 13: 1646-1651. DOI: 10.1016/j.rser.2008.08.009

Srivastava, A. and R. Prasad, 2000. Triglycerides-based diesel fuels. Renew. Sustain. Energy Rev., 4: 111133. DOI: 10.1016/S1364-0321(99)00013-1 